University of South Florida

DIGITAL COMMONS

Digital Commons @ University of

@ UNIVERSITY OF SOUTH FLORIDA

South Florida

Academic Resources Faculty and Staff

Publications

Tampa Library

January 2007

\title{
The Impact of Grey Literature in Advancing Global Karst Research: An Information Needs Assessment for a Globally Distributed Interdisciplinary Community
}

\author{
Todd A. Chavez \\ University of South Florida, tchavez@usf.edu \\ Anna H. Perrault \\ University of South Florida \\ Pete Reehling \\ University of South Florida \\ Courtney Crummett \\ University of South Florida
}

Follow this and additional works at: https://digitalcommons.usf.edu/tlar_pub

Part of the American Studies Commons, Geography Commons, Geology Commons, and the Library and Information Science Commons

\section{Scholar Commons Citation}

Chavez, Todd A.; Perrault, Anna H.; Reehling, Pete; and Crummett, Courtney, "The Impact of Grey Literature in Advancing Global Karst Research: An Information Needs Assessment for a Globally Distributed Interdisciplinary Community" (2007). Academic Resources Faculty and Staff Publications. 14.

https://digitalcommons.usf.edu/tlar_pub/14

This Article is brought to you for free and open access by the Tampa Library at Digital Commons @ University of South Florida. It has been accepted for inclusion in Academic Resources Faculty and Staff Publications by an authorized administrator of Digital Commons @ University of South Florida. For more information, please contact digitalcommons@usf.edu. 


\title{
The Impact of Grey Literature in Advancing Global Karst Research: An Information Needs Assessment for a Globally Distributed Interdisciplinary Community
}

\author{
Todd A. Chavez $\cdot$ Anna H. Perrault $\cdot$ Pete Reehling $\cdot$ Courtney Crummett
}

\begin{abstract}
A survey of the global karst community was conducted in 2006. The survey was distributed via the World Wide Web to known karst researchers. The instrument was designed to generate an initial inventory of core grey information types, to assess levels of usage of grey information by the respondents, and to gauge the karst community's willingness to participate in building and expanding both this collection and the associated controlled vocabularies.
\end{abstract}

Keywords Grey literature - Information needs assessment - Karst research · Karst topography · Geology · Geoscience $\cdot$ Karst Information Portal

\section{Background}

In 2005, an interdisciplinary work group of faculty, librarians, and graduate students was convened under the auspices of the Dr. Kiran C. Patel Center for Global Solutions at the University of South Florida to discuss global information needs. The group quickly focused upon water issues and then more specifically karst, a very complex and vulnerable type of geologic landform [10]. Following these deliberations, the group initiated a study to determine the feasibility of constructing

T. A. Chavez $(\bowtie) \cdot$ P. Reehling

USF Library System, University of South Florida, 4202 E. Fowler Avenue, LIB122, Tampa, FL 33620, USA

e-mail: tchavez@lib.usf.edu

\author{
A. H. Perrault \\ School of Library and Information Science, College of Arts and Sciences University of South \\ Florida, 4202 East Fowler Ave. CIS 1040, Tampa, FL 33620-7800, USA \\ C. Crummett \\ US National Library of Medicine, 8600 Rockville Pike, Bethesda, MD 20894, USA
}


a global information portal to be hosted and maintained by the libraries in collaboration with the Patel Center and related academic departments.

In January 2006, a group of 29 scientists, information specialists, and policy makers representing 18 organizations from across the globe met in Carlsbad, New Mexico to explore development of the Karst Information Portal (KIP) to serve as a repository for karst information, to advance collaboration among the international community of karst researchers, and to promote knowledge discovery through innovative applications of metadata. Figure 1 depicts the architecture of the proposed portal.

\section{The Context}

Karst is a globally distributed terrain resulting from the dissolution of soluble rocks such as limestone and dolomite. This dissolution occurs when rainwater infused with carbon dioxide passes through layers of soil and bedrock (see Fig. 2). Karst regions contain aquifers and common geological structures such as sinkholes, springs, and caves. The relationship between karst landscapes and water resources evokes the need for greater understanding of the issues underlying these formations.

The karst research community and its knowledge base are fragmented, globally distributed, highly interdisciplinary, and at the same time, essential to comprehensive understanding of many social, environmental, and health challenges. In a recent study of four widely used indices covering relevant "white" content, 4,300 individual searches using 632 karst-related terms culled from appropriate thesauri found that, over the period 1960-2005, publication on cave and karst themes has increased substantively [13]. Fifteen years earlier, Bichteler [4] found that grey literature was an important component of the information used by geoscientists. As research into the potential of karst for benefit or hazard to humanity intensifies, information integration and linkages promoting collaboration and connectivity among scientists, decision-makers, educators, and the general public are essential.

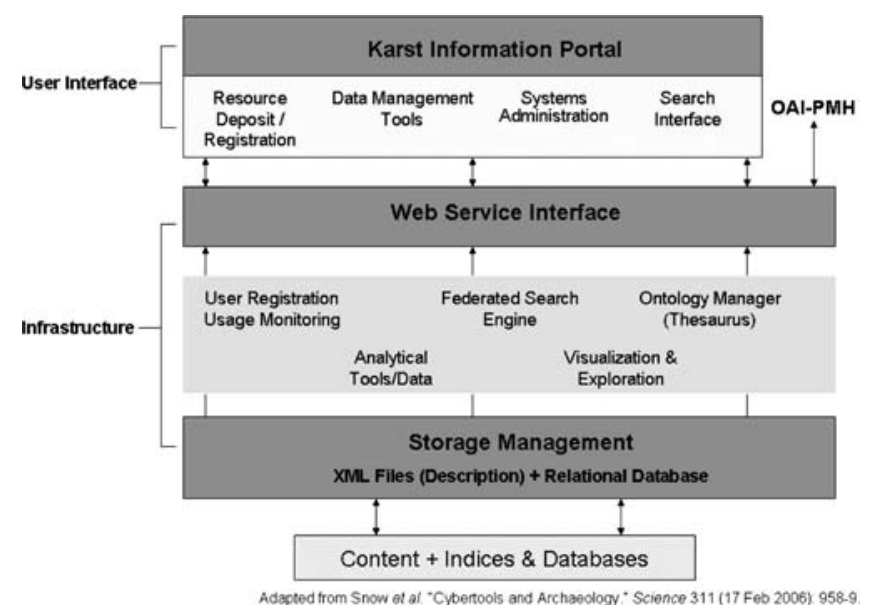

Fig. 1 Graphic representation of the Karst Information Portal 


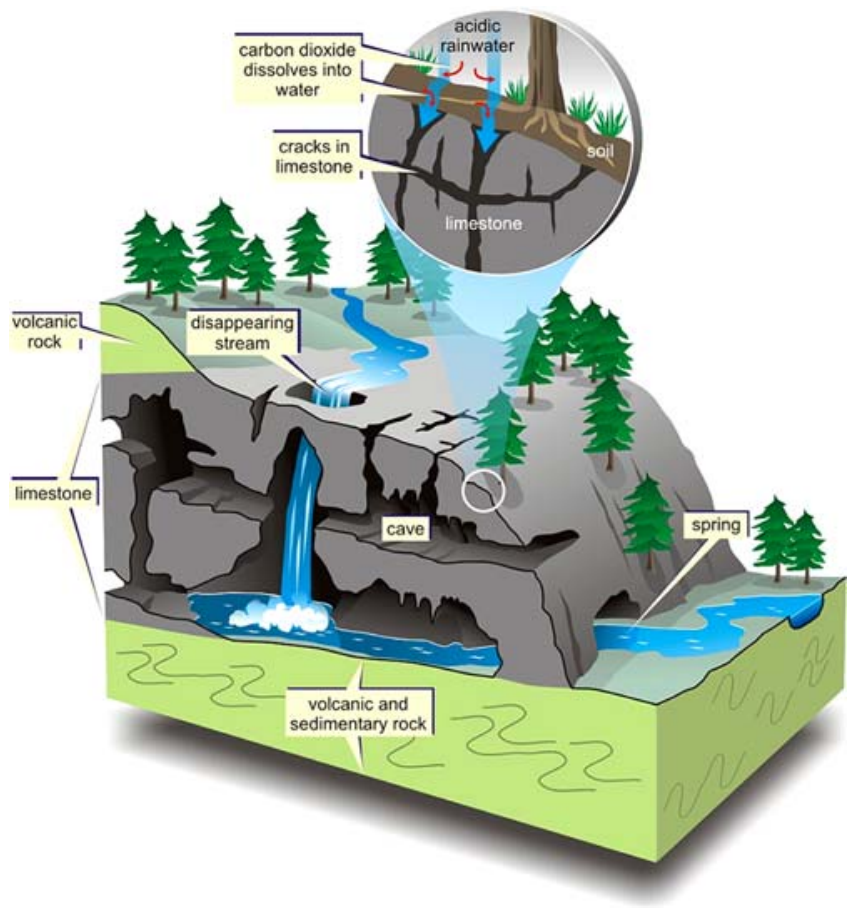

Fig. 2 Karst Terrain (Natural Resources Canada [24])

Karst researchers are faced with three inextricably related challenges: (1) discovering and evaluating relevant information sources, (2) obtaining and preserving "grey" karst information sources, and (3) providing interdisciplinary linkages among karst scientists to bring about knowledge discovery and communication. In order to construct a portal that contained information and services most useful to karst researchers, a needs assessment was performed.

\section{Global Needs Assessment}

Information specialists from the Libraries and the School of Library and Information Science at the University of South Florida planned and conducted a global information needs assessment for the KIP. The survey was designed to elicit responses in three categories of information need: (1) information content (e.g. format, subjects, and organization); (2) services (e.g. blogs, newsfeeds, and tagging services); and (3) research tools (e.g. data-mining and computational utilities).

\section{Instrument Design}

A questionnaire was constructed in Survey Monkey and distributed using a "snowball" sampling technique through targeted websites to reach the global 
interdisciplinary karst community and sent via e-mail to a list of karst researchers compiled during the 2006 KIP Planning Workshop. The recipients of the survey were encouraged to respond and forward the survey on to their colleagues and others interested in karst research in some capacity. It was the hope of the survey team that the list of karst researchers would be enlarged through this process and thus increases the data obtained from the survey.

\section{Results of the Survey}

A total of 66 responses were received (it should be noted that seven of the 19 survey questions permitted multiple responses and for this reason response totals may exceed $100 \%$ ). Although the number of respondents was not large, the sample is broadly representative by geographic region and occupation and interests (see Fig. 3). The countries represented are globally distributed, with the United States and Canada (24) and Australia and New Zealand (17) being the most heavily represented. Responses were also received from six countries in Europe and two responses originated in Malaysia.

The variety of professions or affiliations represented was equally broad, with academic researchers $(41 \%)$, cavers $(20 \%)$, resource managers $(10 \%)$, and students $(10 \%)$ accounting for the majority of respondents. One of the interesting aspects of the distribution of respondents was the proportion who is not academic researchers, cavers in particular who made up one-fifth of respondents. One of the findings, not unanticipated, is that karst researchers make up a similar universe as to that of grey literature, that is, they are hard to find and not under the personal equivalency of "bibliographic control.",

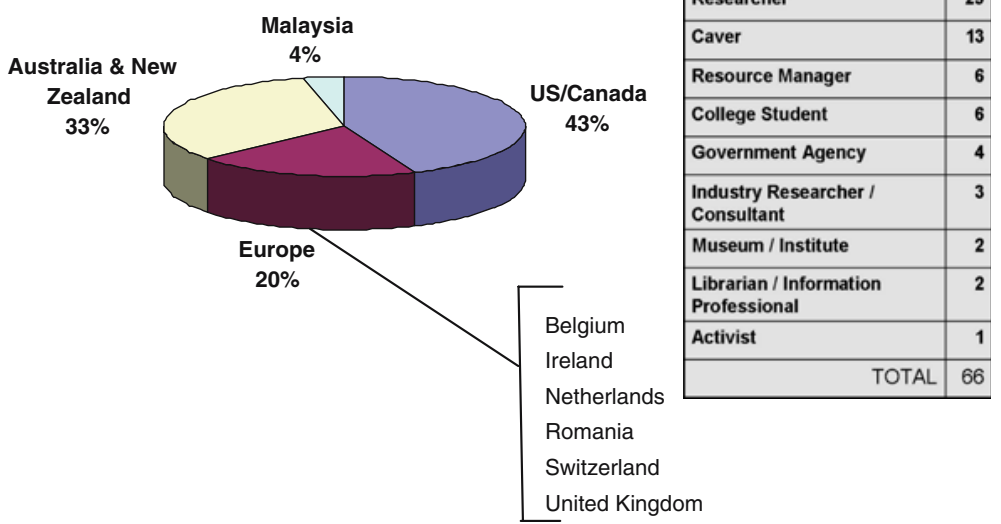

Fig. 3 Geographic and occupational characteristics of respondents 


\section{Locating Karst Information}

Respondents were asked to report on "channels" used to locate information about karst-related subjects. For sources of information, the Internet was indicated by $98 \%$ of respondents. Other sources checked with high frequency were personal correspondence with colleagues (87\%), conferences and meetings $(82 \%)$, and books $(80.6 \%)$. Of the three types of libraries offered for consideration, personal libraries ranked slightly higher than academic libraries, $84 \%$ to $81 \%$. Public libraries had much lower use at $19 \%$ (see Table 1).

These findings are consistent with information-seeking behavior research which has shown that people turn to family or friends as their first source of information and only after those close personal sources do they use more formal sources such as libraries [5, 14, 17, 28]. In the specific case of geoscientists, Bichteler [3] found that personal contacts were extremely important sources of information, particularly when time constraints are significant. Among the two most numerous respondent categories, academic researchers and cavers, personal communications are extremely important, with $100 \%$ of the cavers and $82.7 \%$ of the researchers using personal contacts and colleagues as a source of information.

Although their conclusions are limited to a U.S. context, researchers associated with the Pew Internet \& American Life Project report that $73 \%$ of all American adults regularly use the Internet to access information, by far the most common source of information after family and friends [20: 3]. This trend was also observed in the present study.

\section{Context for Grey Literature in Karst Research}

Using information derived from interviews conducted during the January 2006 KIP Planning Workshop and with reference to the literature [15, 30], an extensive list of 46 information types and formats that could be considered grey literature was compiled for the survey. To build a shared understanding of the terminology,

Table 1 Information channels used by survey respondents

\begin{tabular}{lc}
\hline Sources of Karst Information & No. \\
\hline Internet & 61 \\
Personal correspondence w/colleagues & 54 \\
Journal articles & 53 \\
Personal library & 53 \\
Conferences/Meetings & 51 \\
Books & 50 \\
Academic library & 44 \\
Informal discussion & 44 \\
Public library & 12 \\
Respondents $=62$ & \\
\hline
\end{tabular}


respondents were presented with the definition of grey literature adopted during the Third International Conference on Grey Literature:

" [T] hat which is produced by government, academic, business, and industries, both in print and electronic formats, but which is not controlled by commercial publishing interests and where publishing is not the primary activity of the organization", [12].

The phrase "non-refereed and self-published documents generated by speleological groups and other non-governmental groups/individuals such as expedition reports,", was appended to the core definition to accommodate known grey information types of specific relevance to the karst community.

When asked if the respondents had used grey literature in their work or research, out of 58 responding, $56(96.6 \%)$ said they had. The four most commonly used grey information types are conference proceedings/papers, trip and cave reports, theses/ dissertations, and maps in any format. The reported incidence of use of conference proceedings and papers is consistent with a 2003 study by Michael Noga [25:19] in which the researcher found that citation frequencies of proceedings in a selection of geoscience journals indicated that "conference papers in journals are used to the same extent as research journal articles and that some proceedings are used even more" (for a competing assessment of the use of conference papers in published research, see [19]).

Two subsequent questions were designed to identify the types of grey literature (1) used and (2) produced by survey respondents. A third question used the same list of potential grey information types to identify those that respondents found difficult to locate. Table 2 lists, in declining order of frequency of use, the responses to the three questions. For comparison purposes, levels of use are accompanied by the number of responses for grey information source producers and for respondents reporting difficulty locating particular information types.

Not surprisingly, academic researchers account for a significant percentage (74.1) of respondents who report producing grey information in some format. Roughly $69 \%$ of the researchers contribute to conference proceedings, deliver speeches/ invited talks or generate images while $55 \%$ produce trip and cave reports and $51.7 \%$ create or contribute to cave registries or entrance databases. What is surprising is the finding that $84.6 \%$ of self-identified cavers report producing grey literature, with trip and cave reports and cave registries or entrance databases the most frequent contributions. Responses also indicate that five of the six college or university student respondents produce grey information including conference papers, theses/ dissertations, trip and cave reports, images, datasets, and maps.

It is interesting to note the correlation between the most frequently used sources and levels of production. For example, 42 of the 52 respondents to the question concerning production of grey information report contributing to conference proceedings while 40 respondents generate trip and cave reports. Comparing the pattern of responses reveals potential areas of emphasis for portal designers.

Consistent with the literature, trip and cave reports are a significant form of grey information for geoscientists generally including 18 of 29 academic karst researchers and 11 of 13 cavers responding and as such illustrate the importance of studies that 
Table 2 Responses indicating use, production, and difficulty locating grey information sources

\begin{tabular}{|c|c|c|c|}
\hline \multirow{2}{*}{$\begin{array}{l}\text { Information type (Listed in order of } \\
\text { frequency of use) }\end{array}$} & \multicolumn{3}{|c|}{ Responses (No.) } \\
\hline & $\begin{array}{l}\text { Use type } \\
(N=58)\end{array}$ & $\begin{array}{l}\text { Produce type } \\
(N=52)\end{array}$ & $\begin{array}{l}\text { Difficulty locating type } \\
(N=49)\end{array}$ \\
\hline Conference Proceedings and/or papers & 50 & 42 & 23 \\
\hline Trip and cave reports & 49 & 40 & 16 \\
\hline Theses/dissertations & 47 & 28 & 25 \\
\hline Maps (any format) & 47 & 32 & 14 \\
\hline Non-governmental technical/research reports & 44 & 20 & 20 \\
\hline Websites with karst/geology content & 44 & 18 & 4 \\
\hline Government technical/research reports & 42 & 20 & 21 \\
\hline Images (digital format) & 41 & 34 & 12 \\
\hline Newsletters & 36 & 24 & 9 \\
\hline $\begin{array}{l}\text { Association and organizational publications } \\
\text { and records }\end{array}$ & 34 & 25 & 14 \\
\hline Papers and correspondence of researchers & 29 & 22 & 11 \\
\hline Satellite data & 29 & 3 & 7 \\
\hline Government documents & 28 & 9 & 9 \\
\hline Colleague files & 28 & 12 & 3 \\
\hline Archival materials & 28 & 15 & 10 \\
\hline Geospatial or GIS data & 28 & 15 & 9 \\
\hline Modern photograph collections & 27 & 18 & 8 \\
\hline Cave entrance databases & 27 & 23 & 18 \\
\hline Files in park service offices & 26 & 19 & 13 \\
\hline Preprints & 25 & 18 & 10 \\
\hline Datasets & 25 & 19 & 9 \\
\hline Historical photograph archives & 24 & 8 & 11 \\
\hline Translations of foreign-language publications & 24 & 4 & 15 \\
\hline Monitoring project data & 24 & 15 & 9 \\
\hline Speeches or invited talks & 23 & 34 & 3 \\
\hline $\begin{array}{l}\text { Working papers (i.e., records of individual } \\
\text { or group activities) }\end{array}$ & 23 & 19 & 6 \\
\hline Old published karst papers (pre-1923) & 23 & 0 & 13 \\
\hline Files in government agency offices & 22 & 17 & 11 \\
\hline Consultant's reports & 22 & 17 & 12 \\
\hline Management literature & 22 & 13 & 10 \\
\hline Water-tracing data and databases & 22 & 14 & 10 \\
\hline Videos (digital or analog) & 21 & 13 & 3 \\
\hline Cave registries & 21 & 14 & 12 \\
\hline $\begin{array}{l}\text { International Union of Speleology (UIS) } \\
\text { abstracting products }\end{array}$ & 19 & 7 & 2 \\
\hline Contract reports & 18 & 14 & 10 \\
\hline Oral histories & 18 & 8 & 5 \\
\hline
\end{tabular}


Table 2 continued

\begin{tabular}{|c|c|c|c|}
\hline \multirow{2}{*}{$\begin{array}{l}\text { Information type (Listed in order of } \\
\text { frequency of use) }\end{array}$} & \multicolumn{3}{|c|}{ Responses (No.) } \\
\hline & $\begin{array}{l}\text { Use type } \\
(N=58)\end{array}$ & $\begin{array}{l}\text { Produce type } \\
(N=52)\end{array}$ & $\begin{array}{l}\text { Difficulty locating type } \\
(N=49)\end{array}$ \\
\hline $\begin{array}{l}\text { Catalogs from libraries/collections not } \\
\text { linked in any system }\end{array}$ & 16 & 10 & 10 \\
\hline Research proposals & 15 & 30 & 3 \\
\hline Grant applications & 14 & 23 & 4 \\
\hline Morphology-type databases and collections & 13 & 7 & 5 \\
\hline Statistical documents or reports & 11 & 7 & 3 \\
\hline Research permit system information & 8 & 9 & 3 \\
\hline Databases not linked in any system & 8 & 13 & 5 \\
\hline Registries of current research initiatives & 7 & 5 & 7 \\
\hline Realia and artifacts & 6 & 0 & 1 \\
\hline Audio tapes/files (digital or analog) & 4 & 6 & 0 \\
\hline
\end{tabular}

focus on specific knowledge domains. Bichteler [3, 4], Corbett [7], Derksen [9], Haner [16], and Walcott [31] have independently addressed the specific case of the geological field trip book. Produced by local experts to support excursions into specific field locations, trip and cave reports typically include coverage of transportation resources and relate information about local cultural, geological and geographic features and conditions at a specific point in time [4: 41-42). Both grey and "white" publications often contain citations to trip and cave reports or field books, but, because they are often published by organizations lacking an infrastructure to facilitate wide distribution, librarians are hard pressed to acquire copies and once in hand, cataloging is a challenge [16: 166-7; 31]. It is only through efforts such as The Stanford Geological Survey Map and Field Notebook Project and the Cornell Laboratory of Ornithology's Science Knowledge and Education Network (SKEN) and potentially the KIP - that critical domain-specific grey information is likely to be systematically accessible and preserved [9, 18].

During the January 2006 KIP Planning Workshop, discussions with participants revealed the importance of visual information in geoscience research. In their own right, images, videos, and maps are key sources of information about geological subjects, and they are often integrated into other information types including trip and cave reports, theses/dissertations, and websites. Responses from the four most numerous respondent categories supported this anecdotal conclusion (see Table 3), and coupled with the fact that these formats pose unique challenges for librarians seeking to exert bibliographic control and thereby enhance information discovery and access, suggest a potential content niche for portal planners.

Respondents reported difficulty locating all of the grey information types presented except audio tapes/files. The positive correlation between use and difficulty in locating grey information is relevant in many information type categories but fails markedly in the case of websites with karst/geology contentmany respondents report using them $(n=44)$, but only four indicated that they were 
Table 3 Use and production of images and maps

\begin{tabular}{|c|c|c|c|c|}
\hline & \multicolumn{2}{|l|}{ Images } & \multicolumn{2}{|l|}{ Maps } \\
\hline & $\%$ Use & $\%$ Produce & $\%$ Use & $\%$ Produce \\
\hline Academic researchers & 68.9 & 68.9 & 75.8 & 55.5 \\
\hline Cavers & 46.0 & 53.8 & 76.9 & 61.5 \\
\hline Students & 50.0 & 33.3 & 83.0 & 33.3 \\
\hline Resource managers & 83.3 & 33.3 & 66.6 & 0.0 \\
\hline
\end{tabular}

encountering difficulties. This bodes well for the directions outlined by KIP planners in that, if properly designed and maintained, the site can have a significant positive impact for karst researchers seeking related information, regardless of format. The number of respondents encountering difficulties in locating theses/ dissertations, association publications and records, and pre-1923 karst papers suggests that digitization is an important service dimension, a finding confirmed by responses to subsequent questions.

It was somewhat surprising to learn that relatively few respondents reported difficulty locating karst-related geospatial or GIS data. Just over $43 \%$ of respondents use GIS data and $28.8 \%$ report producing this information type, but only $18.7 \%$ encounter difficulties locating needed geospatial data with academic researchers reporting the lowest level of difficulty $(17.2 \%)$ and students the highest $(33.3 \%)$. Possible explanations for this finding include the substantial efforts of the GIS community to ensure that metadata standards are maintained and systematically applied and the proliferation of geospatial portals on the World Wide Web. Because geospatial/GIS data are by definition born digital, dissemination via the World Wide Web is greatly facilitated.

Finally, several questions presented an array of potential activities, services, and capabilities that are being considered for inclusion in the KIP and asked respondents to rank their importance with the context of their research interests. Embedded within these questions were additional queries about grey literature. In all instances, respondents considered treatment of grey information a key function of the portal:

- $99 \%$ considered grey literature's inclusion very or somewhat important;

- $96 \%$ rated grey literature digitization very or somewhat important; and

- $85 \%$ responded that evaluating the authenticity/reliability of karst-related grey literature was an important portal service.

\section{Archiving Grey Literature}

Bichteler [4: 49) describes the important role that geologists play in preserving the grey information that they produce. Survey responses suggest that this dimension of grey information management continues to pose challenges. Eighty-nine percent of the respondents to the survey reported that they produce grey information in some form, but an alarming $28.3 \%$ do not formally archive their information and just over 
$75 \%$ reported using a personal archiving space. This trend is not limited to a single format of grey information-in 2002, Maples et al. [21:11] warned that the geoscience community must act to preserve data and collections of physical items under a schema that incorporates a standard format for bibliographic citation promoting discovery and access.

Within the four most numerous respondent categories, $68.9 \%$ of the academic researchers reported that they formally archive their grey information in some manner, with resource managers reporting archival efforts in $66 \%$ of cases. Cavers and college or university students similarly archive grey information (61.5 and 50\%, respectively). One observation is warranted: despite likely ease of access to academic libraries, only 12 of 29 academic researchers use libraries or repositories as archival resources, a finding that suggests potential opportunities for librarians (Fig. 4).

Any archival strategies must take into account an issue not anticipated at the onset of the survey, namely the matter of data sensitivity and the potential for improper use of contributed data in two areas of inquiry: cave entrance locations and water-tracing information. According to unsolicited comments, when asked if they would use the KIP as a personal digital repository, a number of respondents were concerned that cave entrance locations remain non-specific to protect fragile cave ecosystems from potentially damaging visits by non-specialists. Similar concerns for water-tracing data were also expressed: precise descriptions of hydrologic systems could endanger the resources by enabling resource destruction through casual and more nefarious activities.

Concerns for copyright protections, attribution, and information authority/ reliability were also expressed, and were anticipated when the survey was designed. Mechanisms for managing these concerns are known and are presently within the expertise of the library and information science community.

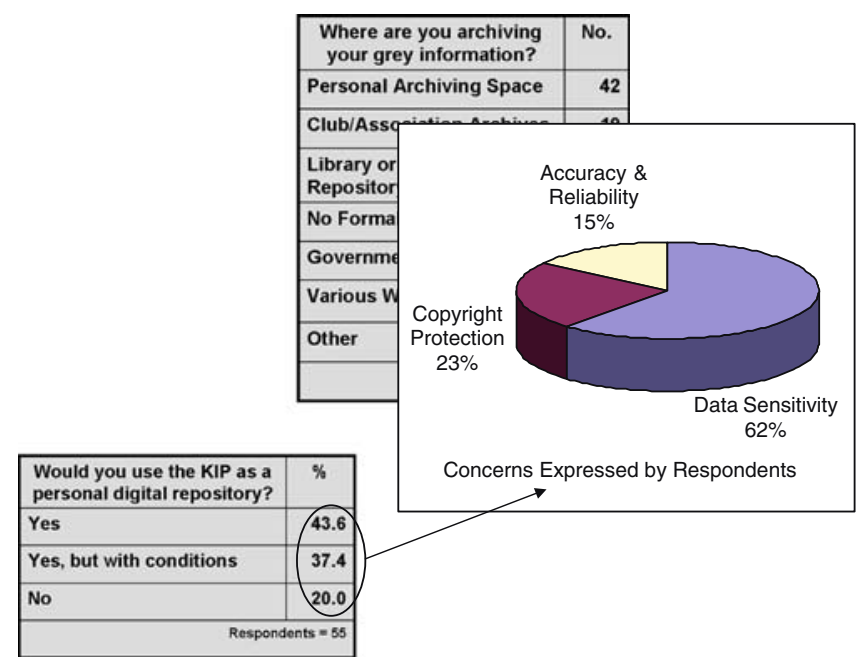

Fig. 4 The KIP as grey information repository 


\section{Karst Information Portal Services and Capabilities}

In addition to the role of the KIP in preserving and providing physical and intellectual access to grey literature, other questions focused on its potential for developing connectivity and promoting collaboration via services or capabilities such as file sharing, RSS feeds, blogs, data management tools, web indexing, and directory services. The select list of potential services or capabilities was developed during the January 2006 KIP Planning Workshop. Tables 4 and 5 summarize responses to these queries.

Early investigations into the role of grey literature in karst research conducted during the January 2006 KIP Planning Workshop suggested that evaluating the authenticity and reliability of grey information was a controversial portal function. Anecdotal evidence indicated that many workshop participants felt palpable distrust of any attempt to assess levels of authenticity or reliability despite their concerns for

Table 4 Potential Karst activities

\begin{tabular}{lllll}
\hline KIP activities: Importance to respondent research & $\begin{array}{l}\text { Very } \\
\text { important }\end{array}$ & $\begin{array}{l}\text { Somewhat } \\
\text { important }\end{array}$ & $\begin{array}{l}\text { Not } \\
\text { important }\end{array}$ & $\begin{array}{l}\text { No } \\
\text { opinion }\end{array}$ \\
\hline Digitize key grey literature resources & 37 & 14 & 1 & 1 \\
Develop potential Karst DBs & 34 & 17 & 0 & 2 \\
Evaluate authenticity \& reliability of Karst-related & 24 & 21 & 7 & 1 \\
$\quad$ grey information & 22 & 24 & 6 & 2 \\
Identify global KIP partners & 20 & 27 & 6 & 1 \\
Develop registry of Karst programs \& conferences & 19 & 33 & 3 & 1 \\
Develop registry of Karst community & 18 & 27 & 9 & 1 \\
Build digital collection of Karst policy resources & 14 & 26 & 10 & 3 \\
Build digital Karst image collection & & & & \\
n = 55 & & & & 3 \\
\hline
\end{tabular}

Table 5 Potential portal content

\begin{tabular}{lllll}
\hline $\begin{array}{l}\text { Materials to include in the KIP: Importance to } \\
\text { respondent research }\end{array}$ & $\begin{array}{l}\text { Very } \\
\text { important }\end{array}$ & $\begin{array}{l}\text { Somewhat } \\
\text { important }\end{array}$ & $\begin{array}{l}\text { Not } \\
\text { important }\end{array}$ & $\begin{array}{l}\text { No } \\
\text { opinion }\end{array}$ \\
\hline Key Karst information sources & 39 & 16 & 1 & 0 \\
Grey literature & 34 & 21 & 1 & 0 \\
Speleological literature DB & 32 & 16 & 7 & 0 \\
Karst community contact information & 23 & 28 & 3 & 0 \\
Karst specific GIS data & 22 & 22 & 8 & 1 \\
Data & 19 & 25 & 6 & 3 \\
Karst image DB & 12 & 26 & 11 & 4 \\
Multilingual dictionary \& controlled vocabulary & 9 & 24 & 15 & 4 \\
$\quad$ Thesaurus) & & & & \\
Respondents = 55 & & & & \\
\hline
\end{tabular}


these qualities in grey literature generally. This finding was borne out by survey responses, with $28 \%$ of academic researchers responding to the questioning judging that this function was not an important portal service. In contrast, all of the cavers and four of the five college or university students responding to the query considered evaluation of grey information very or somewhat important.

Although the predominance of interest in services and collections relevant to grey information is readily apparent, significant support for such services as file sharing, analytical tools, and email is documented in the survey results (see Table 6). Given developments in search engine performance, it is notable that such a large percentage of respondents continue to rank searchable link collections and search tools (83.9\% and $60.7 \%$ respectively) as important for inclusion in the portal. The authors interpret these results as indicators of the continued relevance of domain-specific information portals as mechanisms to promote information discovery in specialized areas.

\section{Participation in and Support for the KIP Project}

At the conclusion of the survey, respondents were queried regarding potential involvement in portal design, development, and maintenance activities. Fifty-four percent of the respondents indicated that they would prefer participation as a "General User," while 34.5\% indicated participation preference as a "Minor Contributor.' Only six of the 55 respondents to this question indicated willingness to serve as a major contributor or project partner. Given the sampling methodology, it is difficult to interpret the impact of this distribution of responses in the context of project sustainability.

Table 6 Potential services and capabilities

\begin{tabular}{lr}
\hline $\begin{array}{l}\text { What types of services or capabilities would make a portal } \\
\text { valuable to you? }\end{array}$ & No. \\
\hline Searchable collection of Links to Karst information & 47 \\
Access to and evaluation of grey literature & 45 \\
Search tools & 34 \\
File sharing services & 30 \\
Member directory & 21 \\
Tools for analyzing data & 21 \\
Capabilities to export bibliographic data & 20 \\
Tools for creating customized DBs & 19 \\
Email service & 18 \\
Pattern recognition search software & 15 \\
Wikis & 12 \\
RSS feeds & 9 \\
Podcasts & 7 \\
Other (journals) & 2 \\
Respondents = 56 & \\
\hline
\end{tabular}


Twenty-eight respondents provided a comprehensive list of potential professional meetings and conferences amenable to marketing and promoting the project. When asked to suggest appropriate target audiences for the KIP, $96.2 \%$ of the respondents indicated that academic researchers or professors were appropriate, with college or university students $(88.7 \%)$, cavers $(83 \%)$, resource managers $(69.8 \%)$, and museum or institute affiliates $(67.9 \%)$ completing the top five responses. This was an encouraging finding in that it supports the project planners' goal of designing a resource with broad appeal and utility.

\section{Conclusion and Recommendations}

In his piece, "The Role of Grey Literature in the Sciences," Professor Irwin Weintraub [32] asserts that,

In a world in which free trade and instantaneous communication have eliminated many of the barriers to information flow, grey literature is gaining greater importance as a source of information for much of the world's population. It is an indispensable resource for an informed and enlightened public and will undoubtedly continue to serve as a necessary supplement to journal literature well into the future.

This study supported Weintraub's general characterization in the specific case of the interdisciplinary domain of karst studies-the impact of grey information sources on the globally distributed karst research community is significant and, according to their survey responses, growing. This trend is consistent with developments in similarly interdisciplinary research domains including library and information science [1], the health sciences [2, 11], marine and fisheries science [8], economics [22], and transportation studies [26, 27]. Based on the consensus definition presented at the beginning of the instrument, $70.9 \%$ of respondents indicated that grey literature is currently a "very important" source of information for karst researchers, with $14.5 \%$ stating that it will be more important in the future. Several respondents noted that, like astronomy and ornithology, cave and karst research benefits from the activities of non-academic individuals and as such would continue to generate (and consume) grey information. Citing recent articles in the journal Nature, one respondent made specific mention of the "ongoing rebellion" in the peer-review process and its role in promoting the importance of grey information.

Although these responses are consistent with the prevailing trend of increasing use of grey information in geoscience research generally, challenges persist. Fifteen years ago, Bichteler [4] listed limited distribution, poor bibliographic control, and nonstandard formats as the primary challenges for geoscientists as they accessed grey literature (39-40). In 2003, Mary Scott [29] described the state of bibliographic control of pre-1900 geoscience literature as steadily improving, but not yet fully satisfactory (108). The survey respondents' answers to questions concerning difficulties in locating grey information suggest that Bichteler [4] and Scott's [29] conclusions continue to ring true. 
Consider the seemingly innocuous role of grey information citation patterns. In their 1993 analysis of references cited in U.S. Geological Survey publications, Butkovich and Musser [6] found that grey information was frequently incorporated in the text, but was often omitted from bibliographies, a condition that they suggested devalued the material's role in the research process. In her subsequent exploration of this phenomenon in 2002, Musser [23] found that the practice continued and "misleads scholars new to the field, historians of science, and other interested in the preservation of the research resources of the geosciences" (6). Simply improving bibliographic control over grey information and enhancing channels for discovery and access-both primary goals of the KIP initiative-will advance karst research, facilitate informed decision-making, and develop future research agendas, in the process transforming global understanding of karst terrains.

One of the primary purposes of the instrument was to generate an initial inventory of core "grey" information resources as well as gauge the karst community's willingness to participate in building and expanding both this collection and the associated controlled vocabularies. Survey results will assist in formulating guidelines for the collaboration-connectivity requirements of a research community spanning the globe. Future research should focus on (1) developing strategies to address concerns surrounding information security/sensitivity and (2) refining the list of key grey information sources for karst researchers with particular emphasis on those unique to the field.

When implemented, the KIP can serve as a model for similar studies of global interdisciplinary communities and the gathering and synthesis of literature to support the research needs of that community.

\section{References}

1. Aina LO. Grey literature and library and information studies: a global perspective. Int J Grey Lit 2000;1(4):179-82.

2. Alberani V, De Castro Pietrangeli P, Rossi Mazza AM. The use of grey literature in health sciences: a preliminary survey. Bull Med Libr Assoc 1990;78(4):358-63.

3. Bichteler J. Information-seeking behavior of geoscientists. Special Libr 1989;80(3):169-79.

4. Bichteler J. Geologists and gray literature: access, use, and problems. Sci \& Technol Libr 1991;11(3):39-50.

5. Brown ME. A general model of information-seeking behavior. In:José-Marie Griffiths, editor. ASIS '91: Proceedings of the 54th ASIS Annual Meeting, October 27-31, 1991, Washington, DC. Medford, NJ: American Society for Information Science; 1991. p. 9-14.

6. Butkovich NJ, Musser LR. Analysis of references cited in US geological survey bulletins, circulars, and professional papers. In: Connie Wick, editor. Finding and communicating geoscience information: Proceedings of the 28th Meeting of the Geoscience Information Society, October 25-28, 1993, Boston, Massachusetts. Alexandria, VA: Geoscience Information Society; 1994. p. 167-71.

7. Corbett RG. Field trip guidebooks need not be gray literature. In: Lerud JV, editor. Individual workstations: information supermarkets for geoscientists. Alexandria, VA: Geoscience Information Society; 1989. p. 113-22.

8. Cordes R. Is grey literature ever used? Using citation analysis to measure the impact of GESAMP, an international marine scientific advisory body. Can J Inform Libr Sci 2004;28(1):49-67.

9. Derksen CRM, Sweetkind-Singer J. Accessing and preserving field maps and notebooks: The Stanford Geological Survey Map and Field Notebook Project. In: Dunn LG, editor. New heights in geoscience information: access and technology: Proceedings of the 37th meeting of the geoscience 
information society, October 27-31, 2002, Denver, Colorado, USA. Alexandria, VA: Geoscience Information Society; 2003. p. 17-23.

10. Drew D, Hotzl H. editors. Karst hydrogeology and human activities: impact, consequences, and implications. Rotterdam: International Association of Hydrogeologists; 1999.

11. Dunn K. Impact of the inclusion of grey literature on the scholarly communication patterns of an interdisciplinary specialty. In: Work on grey in progress: sixth international conference on grey literature, New York Academy of Medicine, NYAM Conference Center, December 6-7, 2004, New York, NY, USA. Amsterdam: TextRelease; 2004. p. 50-54.

12. Farace DJ. Forward. In: Farace DJ, editor. Perspectives on the design and transfer of scientific and technical information: third international conference on grey literature, Jean Monnet Building, November 13-14, 1997. Luxembourg, Amsterdam: TransAtlantic GreyNet; 1998.

13. Florea L, Fratesi B, Chavez T. The reflection of Karst in the online mirror: a survey within scientific databases, 1960-2005. J Cave Karst Stud 2007; (Forthcoming).

14. Given LM. The academic and the everyday: investigating the overlap in mature undergraduates' information-seeking behaviors. Libr Inform Sci Res 2002;24(1):17-29.

15. Grey Literature Network Service. Document types in grey literature. GreySource: a selection of webbase resources in grey literature. <http://www.greynet.org/greysourceindex.html> (16 July 2006).

16. Haner BE. Guidebook citation patterns in the geologic journal literature: a comparison between 1985 and 1967. In: Ansari MB, editor. Frontiers in geoscience information: Proceedings of the twentyfourth meeting of the Geoscience Information Society, November 6-9, 1989, St. Louis, Missouri, USA. Alexandria, VA: Geoscience Information Society; 1990. p. 159-69.

17. Hertzum M, Andersen HHK, Andersen V, Hansen CB. Trust in information sources: seeking information from people, documents, and virtual agents. Interact Comput 2002;14:575-99.

18. Kelling S, Allen P, Bonney R, Poole A. Building a user base around scientific publications: editing online content and annotating scientific materials. 2004. Cornell Laboratory of Ornithology. 2003. $<$ http://www.birds.cornell.edu/it/docs/report_sken.pdf> (8 January 2006).

19. Lacanilao F. Continuing problems with gray literature. Environ Biol Fishes 1997;49:1-5.

20. Madden M. “'Internet penetration and impact, April 2006.' 2005. Pew Internet \& American Life Project. 2006. <http://www.pewinternet.org/pdfs/PIP_Internet_Impact.pdf> (14 October 2006).

21. Maples CG, Cutler P, Dickenson T. Geoscience data and collections preservation: What can the professional community do now? In: Dunn LG, editor. New heights in geoscience information: access and technology: Proceedings of the 37th meeting of the Geoscience Information Society, October 27-31, 2002, Denver, Colorado, USA. Alexandria, VA: Geoscience Information Society; 2003. p. 11.

22. Mili F. Trends in publishing academic grey literature: examples from economics. Int J Grey Lit 2000;1(4):157-66.

23. Musser LR. What geoscientists cite: a comparative study. In: Dunn LG, editor. New heights in geoscience information: access and technology: Proceedings of the 37th meeting of the Geoscience Information Society, October 27-31, 2002, Denver, Colorado, USA. Alexandria, VA: Geoscience Information Society; 2003. p. 5-10.

24. Natural Resources Canada. What is Karst? 2005. Geoscape Nanaimo: Geoscience for Central Vancouver Island Communities. 27 October 2005. <http://geoscape.nrcan.gc.ca/nanaimo/karst_e.php> (6 June 2006).

25. Noga MM. Conference Proceedings in Geoscience Journals: What's the Use? In: Joseph LE, editor. Geoscience Information Horizons: Challenges, Choices, and Decisions: Proceedings of the 38th Meeting of the Geoscience Information Society, November, 2-6, 2003, Seattle, WA, USA. Alexandria, VA: Geoscience Information Society; 2004. p. 19-35.

26. Osif BA. International transportation literature: an analysis of citation patterns, availability, and research implications to the transportation community. Int J Grey Lit 2000;1(4):149-56.

27. Osif BA. Transportation information: a review of grey literature by format, language, and availability. Int J Grey Lit 2000;1(1):12-17.

28. Savolainen R. Everyday life information seeking: approaching information seeking in the context of 'Way of Life'. Libr Inform Sci Res 1995;17(3):259-94.

29. Scott MW. Status of bibliographic control of pre-1900 geoscience literature. In: Joseph LE, editor. Geoscience information horizons: challenges, choices, and decisions: Proceedings of the 38th meeting of the Geoscience Information Society, November, 2-6, 2003, Seattle, WA, USA. Alexandria, VA: Geoscience Information Society; 2004. p. 105-08. 
30. Sulouff $\mathrm{P}$, et al. Learning about grey literature by interviewing subject librarians. C\&RL News 2005;66(7):510-5.

31. Walcott R. Guidebook problems from a librarian's point of view. In: Ansari MB, editor. Frontiers in geoscience information: Proceedings of the Twenty-Fourth Meeting of the Geoscience Information Society, November 6-9, 1989, St. Louis, Missouri, USA. Alexandria, VA: Geoscience Information Society; 1990. p. 185-92.

32. Weintraub I. The role of grey literature in the sciences. 2000. Brooklyn College Library. <http:// library.brooklyn.cuny.edu/access/greyliter.htm> (15 July 2006). 